\title{
The Role of the Internet in Overcoming Information Barriers: Implications for Exporting SMEs of the East African Community
}

\author{
Neema Mori,, Gibson Munisi**
}

\begin{abstract}
Small and medium-sized enterprises play a significant role in the East African Community, contributing highly to the national income and employing a significant number of people. Exportation provides a great opportunity for these enterprises to expand their businesses and improve their performance. However, they encounter a number of informationrelated barriers before and during exportation. Based on literature, this paper identifies these barriers and discusses how the internet could be used to reduce them. Based on the internet, international business and small business literature, the paper provides propositions and develops a model that will be useful for future studies in this area.

Keywords: SMEs; Information barriers; Internet; Exportation; East African Community.
\end{abstract}

\section{Introduction}

In the last few years, the use of the Internet in the East African community (EAC) has grown thanks to the introduction of international fibre bandwidth in these countries in 2010. This has facilitated high access to the Internet as it has become relative cheaper and more reliable (Lange, 2011). Also, the use of mobile telecommunications has increased access to the Internet for many people in the region, not only in big cities but also in remote areas where a large proportion of the population still lives. This arrival of bandwidth has been received with great optimism by various stakeholders in the EAC. As part of the on-going process, it is believed that proper use of the Internet could have positive effect on the lives of many East Africans through enhanced communication and information technologies.

\footnotetext{
* Corresponding author: Neema Mori, Kristiansand School of Business, University of Agder, Boks 422, 4604 Kristiansand, Norway and University of Dar es Salaam Business School, Tanzania, neemagm@uia.no.

** Kristiansand School of Business, University of Agder, Boks 422, 4604 Kristiansand, Norway, gibson.h.munisi@uia.no.
} 
One important business area in which the EAC countries have started benefiting from Internet access is exportation (Boateng, Hinson, Heeks, \& Molla, 2008). Most businesses in the EAC are small and medium-sized enterprises (SMEs). SMEs play a significant role in the world's economy (Anderson, 2011; Dietl, 2005; KyereboahColeman \& Amidu, 2008). Grossman and Helpman (1989) further show that SMEs are able to grow because of improvements in technology, which enable them to introduce new products and services. Because of their growth, SMEs are able to make a major contribution to the national income and employ a significant number of people. Furthermore, SMEs are major players in exportation, as they are often involved in the production and export of goods and services (Knight \& Kim, 2009).

However, SMEs from the EAC are not performing well in exportation because of the various export barriers they face (Husein, 2009; Milanzi, 2012). Because of this, EAC countries' involvement in exportation is low compared with other regions and continents and, as a result, they are lagging behind in terms of economic and social development (Asiedu, 2004; Bakunda, 2003). For those that are participating in exporting, their performance is not as good as expected. One of the barriers to exporting facing these SMEs is their poor access to and knowledge of information and communications technologies (Ernst \& Young, 2009; Anderson, 2011).

The use of the Internet as an important communication tool could help prevent SMEs from being left behind (IFC, 2012). Together with the business experience SMEs already possess, they could make use of the Internet to facilitate their operations, particularly for accessing international markets. In the light of this, the objectives of this paper are to (1) identify and discuss the information-related barriers faced by exporting (and non-exporting) SMEs in the EAC; (2) discuss the role of the Internet in helping to reduce these barriers and enhance SMEs' export performance.

A full evaluation of the implications of Internet use for SMEs' export performance may require a thorough empirical analysis. This paper therefore provides a foundation for such analysis by providing a descriptive analysis, propositions and a model that can be used in future research to empirically explain the relationship between the information-related barriers facing SMEs, the use of the Internet, and SMEs' export performance.

The rest of this paper is organized as follows. The next section presents the methodology used in this study. This is followed by a background section discussing the Internet and exportation by SMEs. The EAC is introduced after this. The following section describes the role of the Internet as regards SMEs and develops propositions and a model. The final section presents the conclusion, theoretical and practical implications and areas for future research.

\section{Methodology}

This paper uses two methods, literature review and secondary data analysis. The review of literature methodology, as argued by Boateng et al (2008), enables researchers to identify critical knowledge gaps, to alert other researchers to opportunities for further 
contributions and to chart a course for future research. We therefore start by reviewing the global literature on the Internet and exportation. This is followed by a literature review on SME exportation in terms of the opportunities and challenges faced when seeking to export. Since the study focuses on discussing the implications for the EAC, a related literature search was conducted, followed by the gathering of secondary data, both looking at the background of the community, SMEs' exports from it and the information-related barriers facing SMEs there. The literature review and secondary data analysis (provided in tables 1, 2 and 3 ) led to the development of propositions and a conceptual model that suggests that the Internet has a direct and moderating effect on overcoming information barriers and improving SMEs' export performance.

\section{The Internet and SME Exportation}

\section{The Internet: Meaning and business use}

The Internet is regarded as one of the extensive forms of communicating, and the one with the great business potential, worldwide (Shabazz, 2000). Obra, Cámara, \& Meléndez (2002) describe the Internet as an international computing system that enables firms to exchange information internally and communicate externally with other organizations. Hamill (1997a) lists users of the Internet as including individuals, companies, governments, universities, research establishments and many others. As a component of information technology (IT), the Internet gives users the ability to exchange, integrate and manipulate data (text, video graphics, and audio) over long distances at high speed (Shabazz, 2000). Similar to Obra et al. (2002), this study defines internet access as having an Internet Service Provider that will enable the user to visit any website, to obtain information from that website, and to send and receive emails and transfer files.

The Internet has many uses and in terms of business usage, as it has been argued that it has been and will continue to be the arena for exchange between buyers and sellers in the future (Abratt \& Silva, 2002). The literature suggests that the Internet is used by businesses in a number of ways. First, it is used for internal and external communication via e-mail. Second, it is used in corporate logistics; for example, multiuser dialogue can be used to achieve "real time" communication across distances. Third, it can provide more rapid access to international markets. Fourth, firms can use it to achieve a competitive advantage, for example, by erecting barriers to entry. Other uses mentioned in the literature include online support for inter-firm collaboration, especially in R\&D, as a tool for searching for and retrieving information, for creating websites for marketing and sales promotion purposes, and for transmitting any type of data (Hamill, 1997a; Grossman \& Helpman, 1989).

These benefits from using the Internet could be far-reaching for SMEs and, when used in conjunction with other resources (such as better managerial support and flexibility), could provide them with a major competitive advantage. Obra et al. (2002) further contend that the Internet can alter an SME's cost structure as it affects the elements needed to manage information, hence enabling their active participation in exportation. 


\section{SME Exportation}

Exporting has traditionally been regarded as the first step in entering international markets (internationalization) and it serves as a platform for future international expansion (Owusu \& Habiyakare, 2011). It is considered a popular strategy for SMEs because it does not require significant resources (Hornby, Goulding, \& Poon, 2002) or a high level of market knowledge or experience (Johanson \& Vahlne, 2009). Internationalization through exporting is also considered a useful way for SMEs to increase their growth. According to the traditional stage theory of the firm (Johanson \& Wiedersheim-Paul, 1975), internationalization is achieved through a developmental and sequential process with the following steps: (i) no regular export activities, (ii) exporting via independent agents, (iii) establishing sales subsidiaries, and (iv) starting production in a foreign country.

Similarly, Bakunda (2003), focusing on exportation by African firms, identifies four stages. He argues that SMEs start out as family-owned businesses, serving the domestic market. Through this process, SMEs are able to make contacts and form network ${ }^{[40]}$. The second stage involves the firms setting up production facilities locally, using imported technology and raw materials, and producing for the local market. In the third stage, the SMEs start to export to neighbouring markets. Finally, they export to overseas markets that are further afield. Bakunda further contends that moving between these stages is associated with three aspects: the presence of networks, international exposure and an understanding of markets.

These aspects are also considered in the revised internationalization process proposed by Johanson \& Vahlne (2009). They argue that, nowadays, the business environment is a web of relationships. Therefore, through interactions and networks, businesses can create knowledge, and channel valuable information and resources, which they can use to identify foreign market opportunities. In other words, firms no longer need to go through each individual stage in order to become international. Networking and interactions are thus important for SMEs in terms of operating in international markets, especially exportation (Zhou, Wu, \& Luo, 2007).

Furthermore, the literature has shown that there are SMEs that start exportation from their inception or after a few years after inception (Zhou et al., 2007). This is argued to be a result of fast-changing economic, technological, social and networking conditions (Johanson \& Vahlne, 2009). One of the frequent motives for exporting is to gain access to new and larger markets in order to achieve growth and, as a result, remain competitive and perform better (Masum \& Fernandez, 2008).

However despite SMEs' willingness and potential for exportation, there are complexities involved that are associated with the distance, risks and other barriers

40 We define networks as a set of long-term contacts between people or organizations in order to get information and build resources. They are further made up of people, who are united by work, friendship, influence or communication. These networks can further be categorized as business and/or social networks. A business network is a set of two or more connected business relationships, in which each exchange is between businesses that are conceptualized as collective actors, while social networks refer to a web of personal connections and relationships for the purpose of securing favours for personal and/or firms' advantage (Anderson, Hakansson, \& Johanson, 1994). 
(Tesfom, Lutz, \& Ghauri, 2006). Due to these barriers, some SMEs decide not to participate in exportation, which puts them at a disadvantage compared to those that engage fully in exportation (Anderson, 2011; Leonidou, 2004).

In this regard, the Internet could be helpful in reducing some of the barriers that are encountered - specifically, the information-related barriers -thereby enabling SMEs to capture the benefits of exportation (Hornby et al., 2002). It could help exporting SMEs to leapfrog the conventional stages of internationalization (Bennett, 1998) and some of the stages of exportation listed by Bakunda (2003) by removing many if not all of the geographical and informational barriers and permitting virtual branches to be established instantly, throughout the world, granting SMEs direct and immediate foreign market entry (Bennett, 1998).

The aim of this paper is therefore to look at how the Internet could specifically reduce the information-related barriers faced by SMEs exporting from the East African region. The paper focuses on this region because of the contextual similarities of the countries, all of which are members of the EAC. As Hornby, Goulding \& Poon, (2002) note, SMEs' export barriers are shaped by the contextual background of the firms, which is why this study focuses on the EAC and draws conclusions based on the information-related barriers that are faced by SMEs in that community. To provide the necessary background, the next section examines the EAC.

\section{The East African Community}

\section{Background}

The EAC is the regional intergovernmental organization of the Republic of Kenya, Uganda, the United Republic of Tanzania, the Republic of Rwanda and the Republic of Burundi ${ }^{[41]}$. The agreement establishing the EAC was signed in November 1999 and came into force in July 2000. The community aims at widening and deepening cooperation among the partner states in, among others, political, economic and social fields, for mutual benefit. To this end, the EAC countries established a Customs Union in 2005 and a Common Market in 2010. The community is currently working on establishing a monetary union and, ultimately, aims to become a political federation of East African countries.

The five partner countries had a combined population of more than 130 million people as of 2010, a land area of 1.82 million square kilometres and a combined gross domestic product of $\$ 74.5$ billion as of 2009 (EAC, 2011b). These features give the EAC great strategic and geopolitical significance and the potential for a renewed and reinvigorated region. Furthermore, the community has vast potential in terms of mineral, water, energy and wildlife resources. It is also currently engaged in agricultural, livestock, industrial and tourism development (EAC, 2011a). The people of this community have a common history, a common language (Kiswahili), and a shared culture and infrastructure

41 Borrowed from the EAC website: http://www.eac.int/about-eac.html. 
(Ernst \& Young, 2009). Table 1 shows selected basic information on the EAC partner countries.

Table 1. EAC Countries: Basic Information

\begin{tabular}{lcccc}
\hline Partner member & $\begin{array}{c}\text { Land area in 000s } \\
\text { sq. kms. }\end{array}$ & $\begin{array}{c}\text { Population in } \\
\text { millions } \\
(\mathbf{2 0 1 0 )}\end{array}$ & $\begin{array}{c}\text { Real GDP in } \\
\text { million USD } \\
\mathbf{( 2 0 1 0 )}\end{array}$ & $\begin{array}{c}\text { GDP per capita } \\
\text { USD } \\
(\mathbf{2 0 1 0})\end{array}$ \\
\hline Burundi & 25.0 & 8.4 & $1,499.1$ & 173.0 \\
Kenya & 580.7 & 38.6 & $18,543.7$ & 833.4 \\
Rwanda & 24.2 & 10.4 & $4,032.6$ & 540.0 \\
Tanzania & 886.3 & 43.9 & $11,941.1$ & 546.7 \\
Uganda & 199.8 & 31.8 & $9,538.9$ & 525.9 \\
East Africa & 1716.0 & 133.1 & $45,555.4$ & 685.0 \\
\hline
\end{tabular}

Overall, this table shows that the EAC has a large potential market in terms of suppliers and customers of various products, and therefore has great potential for accelerating growth and becoming competitive in the global market. This is further shown in the EAC development strategy for the next decade (2011-2020), which is focused on improving global competitiveness so as to provide faster and sustainable economic growth and move closer to the status of a newly industrialized region (EAC, 2011a). The aim is to achieve this through, among other things, the region's active support of its SMEs and improvements in global communications/information technology.

\section{Internet use in the EAC}

In 2010, the region was connected by a second fibre optic cable linking East Africa to the rest of the world, and specifically to Europe. The cable is known as the East African submarine cable system. The cable led to better Internet access and improved connections in the region. The EAC (2011a) report argues that access to and use of information and communications technology (ICT), including the Internet, is essential for the development of the EAC, both from an economic and social viewpoint. The report further shows that ICT is growing at a fast rate in the region, although the statistical indicators used to measure this development may not be completely reliable.

Information from the internetworldstats website ${ }^{[42]}$ further shows that growth in East Africa's internet and broadband sector has accelerated in recent years due to improvements in infrastructure, the arrival of wireless access technologies and lower tariffs. Broadband is rapidly replacing dial-up as the preferred access method in the region. The use of social media such as Facebook, Skype, Linkedln and Twitter is also growing. The website, for example, shows that three EAC partner states (Kenya, Tanzania and Uganda) are among the top ten African countries in terms of number of Internet users. Table 2 shows that in these three countries internet users make up

42 http://www.internetworldstats.com/stats1.htm. 
more than $10 \%$ of the total population. This shows the great potential of the Internet for many endeavours, including participation in international markets through exportation.

Table 2. Internet users (million people)

\begin{tabular}{lrrrc}
\hline \multicolumn{1}{c}{ Country } & Year $\mathbf{2 0 0 0}$ & Year 2011 & \% of population & $\begin{array}{c}\text { \% of population } \\
\text { (Africa) }\end{array}$ \\
\hline Burundi & 3,000 & 176,040 & $1.7 \%$ & $0.1 \%$ \\
Kenya & 200,000 & $10,492,785$ & $25.5 \%$ & $7.5 \%$ \\
Rwanda & 5,000 & 818,048 & $7.2 \%$ & $0.6 \%$ \\
Tanzania & 115,000 & $4,932,535$ & $11.5 \%$ & $3.5 \%$ \\
Uganda & 40,000 & $4,178,085$ & $12.1 \%$ & $3.0 \%$ \\
\hline
\end{tabular}

Source: Internetworldstats.com. Accessed 20th April, 2012.

\section{Exportation from the EAC}

The EAC encourages exports by SMEs and large enterprises. Similar to other African economies, the governments of the partner states have adopted export promotion strategies (Anderson, 2011; Bakunda, 2003). The establishment of the customs union has catalyzed the expansion of trade. Exports between countries within the community (intra-EAC trade) grew by $40 \%$ between 2005 and 2009. For example, Uganda's exports to Kenya increased more than tenfold, while Tanzania's exports to Kenya over the same period nearly tripled (EAC, 2011b). This increased trade and investment among the EAC partner states has broadened the prospects for economic growth and is also expected to extend to other countries globally. Table 3 shows the trend in exports to other parts of the world over the period 2006-2010.

Table 3. Export trends in the EAC (million USD)

\begin{tabular}{lrrrrr}
\hline Country/Year & \multicolumn{1}{c}{$\mathbf{2 0 0 6}$} & $\mathbf{2 0 0 7}$ & $\mathbf{2 0 0 8}$ & $\mathbf{2 0 0 9}$ & \multicolumn{1}{c}{$\mathbf{2 0 1 0}$} \\
\hline Burundi & 15.59 & 10.59 & 10.85 & 18.35 & 117.34 \\
Tanzania & $2,000.12$ & $2,007.00$ & $3,119.30$ & $2,982.45$ & $3,976.79$ \\
Uganda & 962.19 & $1,336.67$ & $1,724.30$ & $1,567.61$ & $1,618.60$ \\
Kenya & $3,481.19$ & $4,080.02$ & $5,054.16$ & $4,462.48$ & $5,180.70$ \\
Rwanda & 143.50 & 183.98 & 399.99 & 211.86 & 237.80 \\
\hline
\end{tabular}

Source: EAC (2011b).

SMEs contribute greatly to exports in this region. Reflecting this, the current EAC development strategy for 2011-2016 indicates that the SME sector forms the bulk of the industrial sector (by number of firms), and contributes more than 60 percent of employment in the region. The strategy indicates further that this sector has the potential to address the development needs of the region, through poverty reduction, technological innovation, economic linkages and the reduction of disparities in regional development, if well supported and brought into the mainstream of the formal economy (EAC, 2011a). As a result, one of the current priorities for the EAC 
is to facilitate the development and growth of SMEs, including helping them to excel in regional and international markets through exportation (Ernst \& Young, 2009; EAC, 2011a). The EAC strategy also mentions that SMEs in the region are currently expanding their businesses to partner states and internationally.

However, SMEs face a number of barriers that hinder them from participating fully in exportation. Delloitte (no year) lists various barriers faced by SMEs in the EAC, including (but not restricted to) the weak labour market, lack of access to finance, international competition, weak management skills, the lack of international experience and poor information technology. Hussein (2009) mentions that similar barriers are faced by Tanzanian exporters. The focus of this paper, however, is on information-related barriers, and the next section describes the types of barriers caused by poor or missing information.

\section{Information-Related Barriers Faced by Exporting SMEs}

Various information-related barriers are faced by SMEs globally. Many of these are also faced by SMEs in the EAC. The following barriers are drawn from the literature, including empirical studies carried out in the EAC:

Lack of information to locate and analyse foreign markets: Many SMEs lack adequate information about foreign markets. Anderson (2011), for example, conducted a study on SME internationalization in Tanzania and found that the export performance of $35 \%$ of SMEs may be affected by this barrier.

Inability to contact overseas customers: The export promotion strategies adopted in many African countries, including those in the EAC, have enabled some SMEs to make contacts in overseas markets (Anderson, 2011; Bakunda, 2003). However, the challenge is the reliability of accessing such contacts.

Inability to identify foreign business opportunities: This is a key aspect of SMEs' export performance. SMEs need to know where they might find business opportunities and where there might be a market for certain products. Anderson (2011) shows that $40 \%$ of exporters obtained their markets through participation in trade fairs. It seems that many exporting SMEs are not able to identify markets, either through trade fairs or any other means. In addition, there seems to be an overall lack of knowledge among SMEs as to how and where they might search for business opportunities (Tesfom et al., 2006).

Distribution channels: The barriers faced by EAC SMEs in this area include gaining access to export distribution channels, the complexity of local and foreign distribution channels, control by foreign middlemen, and long delivery times (Mori, 2010). All of these issues are related to inadequate information. If an SME has more information about the choice of distribution channels available, it will be better able to select the most appropriate one for its needs. Information also gives SMEs more power to deal with middlemen.

Lack of product promotion: The ability to excel at exporting requires that products are promoted effectively. The EAC countries have adopted promotion campaigns and 
export development strategies to boost their export performance. Advertising is one of the most widely used means of communication and promotion in international markets (Darley, 2002). However, SMEs may find it difficult to produce effective advertisements for a number of reasons, including ignorance about what is required, the inability to promote their product to the target audience, and, as a result, inappropriate content in the advertising message. Exacerbating this, the promotion campaigns in the EAC are currently mainly focused on trade fair participation, which is insufficient for improving SMEs' export performance (Mori, 2010).

In summary, barriers associated with communication and access to information seems to be the concern of many of the SMEs engaged in exporting (Delloitte, no year; Tesfom et al., 2006). Clearly these problems need to be tackled. This paper contributes to this objective by analysing how use of the Internet could help SMEs to reduce or eliminate these problems and become more successful in international markets. By taking into account the effects of the internet on exportation, the next section discusses how it could help SMEs to overcome some of the information-related barriers identified in this section. Propositions are stated and a model is presented.

\section{The Role Of The Internet For Exporting SMEs In The EAC}

The Internet provides organizations, including SMEs, with new ways of conducting business by exchanging information and business ideas. This section argues that the opportunities provided by the internet would enable SMEs to overcome informationrelated barriers.

The Internet has the ability to transform an organization's operations if used properly. For this reason, many firms use the Tnternet as a major strategic informational tool. They also use the Internet to gain an edge in an increasingly competitive business environment, both domestically and internationally (Anderson, 2011; Dholakia \& Kshetri, 2004).

\section{International market costs}

Internet technology enables SMEs to improve the efficiency of their performance and develop new ways of coordinating their activities in the international context (Loane, 2005). It offers SMEs an important resource that can be used to carry out export activities cheaply. SMEs which are using the Internet can quickly gain global recognition via a website and email, without too much difficulty. In his study, Bennett (1998) observes that the Internet is a valuable tool for generating sales leads, helping SMEs to sell their products in remote countries, to penetrate unfamiliar markets and to create international awareness. These benefits can be achieved at little cost.

In addition, marketing costs, such as advertising costs, can be significantly reduced as the internet makes it possible to reach a global audience cheaply (Hamill, 1997b). Also, SMEs offering specialized products for a niche market may be able to cheaply find the many customers needed to succeed internationally through the worldwide reach 
of the internet (Hamill, 1997b). Based on the above arguments, we make the following proposition:

Proposition 1: The use of the Internet enables SMEs to reduce the costs of accessing international markets.

\section{Communication with customers}

One of barriers encountered by SMEs is the inability to communicate with overseas customers (Fillis, 2002; Husein, 2009; Leonidou, 2004). The main reasons for this are the large physical and psychological distances involved in reaching international markets and the poor communications infrastructure in many countries (Leonidou, 2004). SMEs can use the internet as a communications tool to overcome this problem if other countries with which they are communicating also have good communications infrastructure. The Internet acts as a global channel through which both existing and potential customers can be targeted. SMEs can use it to publicize their commercial offerings (Melewar \& Smith, 2003).

In addition, according to Poon and Swatman (1999), the most useful function of the Internet is the use of e-mail to conduct business communications. Qualman (2009) also notes that the use of social media such as Twitter and Facebook not only enables social interaction but also the building of business networks. The Internet offers something that telephone and fax services cannot, namely, asynchronous communication, which overcomes time and geographic limitations, and electronic document transmission (Poon \& Swatman, 1999).

Thus, SMEs could use the Internet as a communications tool to facilitate interaction with overseas customers. This leads to the following proposition:

Proposition 2: The Internet facilitates SMEs' communication with overseas customers.

\section{Distribution channel's effectiveness and efficiency}

Having an effective distribution channel is one of the most important factors for ensuring that the export business is successful. In many trading activities, the distributors are the key link between the manufacturer and the customer (Tesfom et al., 2006; Wilkinson \& Brouthers, 2006). However, the ability of SMEs to access appropriate distribution channels can be hampered by a number of factors, such as competition from large firms that already control distribution, physically long channels that drive up the costs to a level that SMEs cannot afford, and a system in which the distributors have an excessive amount of control and SMEs have weak bargaining power (Wilkinson \& Brouthers, 2006).

The Internet helps SMEs to overcome these problems because they could use it to eliminate redundant processes and establish direct links with customers. By connecting end-users and producers directly, the Internet reduces the importance of traditional intermediaries in international markets, thus speeding up SMEs' entry into the export business (Hamill, 1997b). Thus, the following proposition is posited. 
Proposition 3: The use of the Internet reduces SMEs' distribution channel barriers.

\section{Selling to foreign market customers}

The Internet enables SMEs from the EAC to instantaneously position themselves in many foreign markets at the same time (Bennett, 1998). As a result, customers would have the opportunity to search and buy from any place in the world and at any particular time via firms' websites. Thus, use of the Internet would enable SMEs to overcome foreign customers' accessibility problems. For example, information could be accessed via the web about small hotels and tour operators located in remote areas of Tanzania and Burundi. Websites provide information about the services a firm is offering customers located anywhere in the world, which could be accessed at any time. As a result, SMEs are able to access international markets directly via their websites, and export the goods or services demanded by foreign market customers. This leads to the following proposition.

Proposition 4: The Internet enables SMEs to market and sell their products to foreign customers.

\section{Risk assessment and the identification of business opportunities}

One of the main barriers hindering SMEs from exportation is that it is difficult for them to identify foreign business opportunities (Leonidou, 2004). This has been highlighted as a problem for SMEs from the EAC (EAC, 2011a). The internet provides the opportunity for firms to identify, access and utilize new business opportunities, for example, by facilitating the search for and retrieval of information (Peterson, Balasubramanian, \& Bronnenberg, 1997). For example, firms can find business partners on the web, via networks of suppliers and customers of various goods and services set up specifically to provide opportunities for trade. There are a number of websites providing this type of service (Bennett, 1998). SMEs could use these types of networks, and other opportunities offered by the Internet, to interact, form business contacts and identify foreign business opportunities.

Exportation is typically perceived as a risky undertaking for any firm regardless of size (Ghoshal, 1987; Johanson \& Vahlne, 2009). According to (Ghoshal, 1987), an international firm faces many kinds of risk, some endemic to all firms and others unique to organizations operating across national boundaries. These perceived risks can often be a major hindrance to an SME aiming to export, particularly as they may lack adequate information about foreign markets that might help mitigate such risks (Johanson \& Wiedersheim-Paul, 1975).

It can be costly for SMEs to access this information; as a result, they may be at a disadvantage compared to large firms with a huge amount of resources. However, if SMEs started using the internet it would alter the situation in their favour, as it would provide a vast amount of information that could be used to assess the risks associated with international business and to identify appropriate new opportunities in foreign markets. On the basis of this argument, the following proposition is suggested. 
Proposition 5: The use of the Internet assists SMEs to assess the risks in international markets and to identify appropriate business opportunities.

\section{Global marketing Promotion}

By using the Internet as a communications tool, SMEs in the EAC would be able to devise suitable global marketing strategies. Having a presence on the web means that a firm is international (Yi-Long \& Chun-Liang, 2006). The internet can be used as a fullyfledged global marketing communications channel, and can deliver many aspects of an organization's global marketing strategy, including branding, database building, and customer acquisition, providing customer services, forming relationships and building loyalty (Melewar \& Smith, 2003).

This is particularly relevant for SMEs that have been unable to compete on a global scale through lack of means. With growth in its use and because it is not constrained by either time or location, the Internet has the potential for mass communication and advertising with negligible costs per customer. This leads to the following proposition.

Proposition 6: The use of the Internet increases SMEs' ability to devise global marketing strategies.

\section{The Conceptual Model}

The discussion and propositions above have argued that the use of the Internet could have a direct effect on an SME's export performance and a positive moderating effect on the relationship between information-related barriers and export performance. SMEs from the EAC could overcome information-related barriers by having easier access to information at a relatively low cost as a result, enhancing their export performance. Figure 1 shows the conceptual framework summarizing the above arguments and propositions.

The model indicates that information-related barriers may lead to poor export performance by SMEs. However, by using the Internet, SMEs are able to overcome some of these barriers and improve their export performance. In essence, Internet use has a moderating effect on the relationship between information barriers and SMEs' export performance. In addition, Internet use has some direct positive effects on SMEs' export performance. This implies that, even if using the Internet does not reduce or eliminate the information-related barriers encountered, it could still have a direct positive effect on export performance. And this may be the case especially for SMEs in the EAC who start exporting from inception. Thus, we argue that SMEs from the EAC that use the internet in their business operations will do better at exporting than those that do not. 


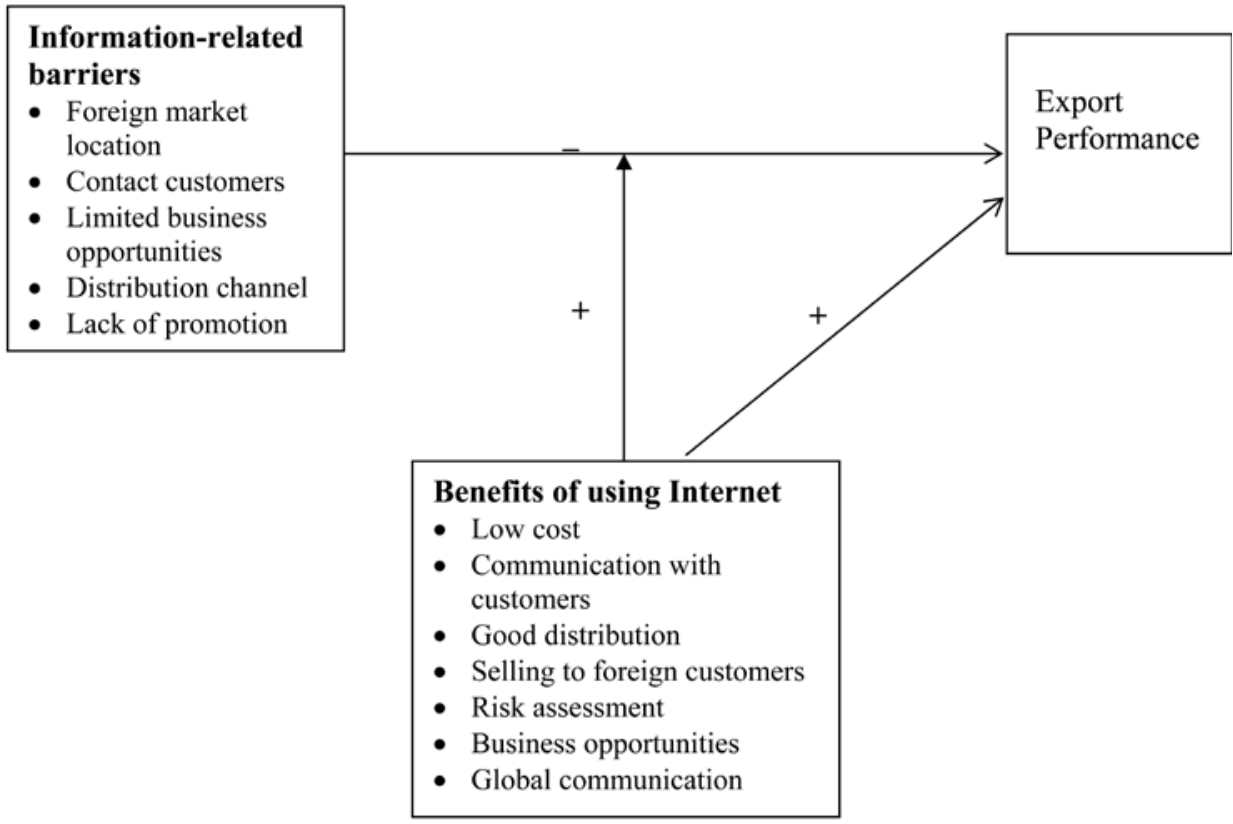

Figure 1. The effect of the internet on SMEs' export performance

This model has some limitations. First, it only considers information-related barriers and ignores other barriers. We do this purposely, since the focus of this study is on information-related barriers. We are aware that other barriers are faced by SMEs that affect export performance (Leonidou, 2004; Anderson, 2011). These barriers relate to market orientation, innovation, product development, management problems and lack of infrastructure. They have very little to do with the internet and much more to do with leadership, management and financial resources. Second, our model only looks at how export performance could be improved as a result of internet usage. From the literature, we know that SMEs' export performance is also affected by other factors such as managerial capacity, experience, resource availability and organizational culture (Myszak, 2010; Tesfom et al., 2006). These factors are not discussed in our model and future studies should take them into consideration.

\section{Conclusion and Implications}

This paper analysed the information-related barriers facing SMEs in the EAC, and how the Internet could help to overcome these barriers and improve export performance. The paper argues that, if SMEs were to use the Internet efficiently, their export performance would improve due to their exploitation of the distinctive features of the Internet. The paper has various implications. 


\section{Theoretical Implications}

This paper contributes to the internationalization process model that was revised in 2009. In this model, Johanson \& Vahlne (2009) argue that firms nowadays create new knowledge through exchanges and interactions via business networks of interconnected relationships. This paper contributes to this angle by showing how the Internet could be used as a means of interacting and forming business networks. When SMEs are able to form these networks, their participation in exportation and international markets is likely to improve. We further contribute to the discussion on the ability of SMEs to identify and utilize business opportunities through the internet. Similar to Johanson \& Vahlne (2006), this paper argues that developing business opportunities and improving export performance through use of the Internet is an interactive process, characterized by a gradual increase in SMEs' learning and commitment to utilizing such opportunities.

The resource-based view of the firm suggests that firms can build competitive advantage through utilizing their unique resources (Barney, 1991). Teo \& Pian (2003) show the positive relationship between the level of internet use and the competitive advantage of large firms. This paper contributes to this research area by showing how SMEs could use the internet to reduce information barriers and as a result build competitive advantage that would enable them improve exportation and compete internationally.

\section{Practical Implications}

This paper has specific implications for SMEs in the EAC. First, the EAC is making an effort to improve its participation in international business, and the use of the Internet could contribute to the success of this strategy. A report by the EAC (2011b) shows that the use of the internet and IT is expanding rapidly in the region. This paper argues that the EAC should make more effort to measure the growth rate of internet usage and identify how it could help SMEs within the community to participate in exporting and in other forms of internationalization.

Although the Internet has a direct effect on information-related problems, it could also indirectly affect firms' overall export performance as information is vital if they are to be successful in this regard. We argue that, because of the unique features of the Internet, it could act as a source of competitive advantage for SMEs, particularly those engaged in exporting. SMEs in the EAC should increase their use of the Internet, specifically social media and websites, to market their products and discover new business opportunities.

Although the Internet is important, it is not the only solution for exporting SMEs in the EAC. SMEs should be aware that, despite the Internet's advantages, there are costs associated with its use. Care should be taken in selecting what information to display and what not to display (Qualman, 2009). They should also realize that there is always competition out there and that, sometimes, putting a firm online may mean opening it up to greater competition. These could be the gains for not using the Internet. 


\section{Limitations and Future Research}

This paper is limited as it lacks a thorough empirical aspect. However, the model and propositions developed here are a good foundation for an empirical study to be conducted in the East African setting in the future. Also, the paper focuses on the effects of the Internet on information-related barriers. The literature shows that there are other barriers and other factors that affect SMEs' export performance. Anderson (2011) examined other factors in the Tanzanian context, for example. Future research could utilize the arguments put forward in this paper, and borrow others from the related literature, to examine what other factors are important for EAC SMEs' participation in exportation.

We acknowledge the fact that we studied the Internet as a contribution to enhancing SMEs' export performance. It is possible that there is a reverse relationship in that the development of SMEs is the reason for the tremendous growth in Internet use. This is another limitation of our study and future empirical studies should take this into consideration.

This paper is also limited in that it only looks at the exportation mode of the internationalization process. There are other SMEs in the EAC that participate or would like to participate in licensing, franchising, joint venturing, strategic alliances and foreign direct investment (Owusu \& Habiyakare, 2011). These SMEs may face different barriers that are worth investigating.

\section{References}

Abratt, R., \& Silva, L. H. D. (2002). Potential of the internet as a retailing channel in South Africa. Journal of African Business, 3(3), 69-90.

Anderson, W. (2011). Internationalization opportunities and challenges for small and medium-sized enterprises from developing countries. Journal of African Business, 12(2), 198-217.

Asiedu, E. (2004). Policy reform and foreign direct investment in Africa: Absolute progress but relative decline. Development Policy Review, 22(1), 41-48.

Bakunda, G. (2003). Explaining firm internationalization in Africa using the competence approach. Journal of African Business, 4(1), 57-85.

Barney, J. (1991). Firm resources and sustained competitive advantage. Journal of Management, 17(1), 99-120.

Bennett. (1998). Using the World Wide Web for international marketing: Internet use and perceptions of export barriers among German and British businesses. Journal of Marketing Communications, 4(1), 27-43.

Boateng, R., Hinson, R., Heeks, R., \& Molla, A. (2008). E-commerce in least developing countries: Summary evidence and implications. Journal of African Business, 9(2), 257-285.

Jerzy Dietl, J. (2005). Expansion of Marketing Activities and Marketing as a Field of Science and Education Subject. Journal of Entrepreneurship, Management and Innovation, 2(1), 4-23 
Delloitte. (no year). Ethics and governance in SMEs - East Africa's experience. From http://www.benafrica.org/downloads/Mponji,\%20Simon.pdf.

Dholakia, R. R., \& Kshetri, N. (2004). Factors impacting the adoption of the internet among SMEs. Small Business Economics, 23(4), 311-322.

EAC. (2011a). EAC development strategy: Deepening and accelerating integration., (pp. 215). Arusha, Tanzania: The East African Community.

EAC. (2011b). The East African Community facts and figures. (pp. 66). Arusha, Tanzania: The East African Community.

Ernst \& Young. (2009). Study on the promotion of micro, small and medium enterprises in the East African region (pp.88). The East African Community.

Fillis. (2002). Barriers to internationalisation. European Journal of Marketing, 36(7/8), 912. Ghoshal, S. (1987). Global strategy: An organizing framework. Strategic Management Journal, 8(5), 425-440.

Grossman, G.,\&Helpman, E. (1989). Growth and Welfare in a Small Open Economy. NBER Working paper Series. Number. 2979

Hamill, J. (1997a). The internet and international marketing. International Marketing Review, 14(5), 300-323.

Hamill, J. (1997b). Internet marketing in the internationalisation of UK SMEs. Journal of Marketing Management, 13(1-3), 9-28.

Hornby, G., Goulding, P., \& Poon, S. (2002). Perceptions of export barriers and cultural issues: The SME's e-commerce experience. Journal of Electronic Commerce Research, 3(4), 213-226.

Husein, A. (2009). Determinants of firms' export performance: Empirical evidence from Tanzanian manufacturing firms. Masters in International Management, University of Agder.

IFC. (2012). Doing business in the East African Community. pp. 116.Washington.

Johanson, J., \& Vahlne, J.-E. (2006). Commitment and opportunity development in the internationalization process: A note on the Uppsala internationalization process model. Management International Review, 46(2), 165-178.

Johanson, J., \& Vahlne, J.-E. (2009). The Uppsala internationalization process model revisited: From liability of foreignness to liability of outsidership. Journal of International Business Studies, 40, 1411-1431.

Johanson, J., \& Wiedersheim-Paul, F. (1975). The internationalization of the firm - four Swedish cases. Journal of Management Studies, 12(3), 305-323.

Knight, G. A., \& Kim, D. (2009). International business competence and the contemporary firm. Journal of International Business Studies, 40(2), 255-273.

Kyereboah-Coleman, A., \& Amidu, M. (2008). The link between small business governance and performance: The case of the Ghanaian SME sector. Journal of African Business, 9(1), 121-143.

Lange, P. (2011). Africa - internet, broadband and digital media statistics 69. Retrieved from https://www.budde.com.au/Research/Africa-Internet-Broadband-and-DigitalMedia-Statistics-tables-only.html 
Leonidou, L. C. (2004). An analysis of the barriers hindering small business export development. Journal of Small Business Management, 42(3), 279-302.

Loane, L. S. (2005). The role of the internet in the internationalisation of small and medium sized companies. Journal of International Entrepreneurship, 3(4), 263-277.

Masum, M. I., \& Fernandez, A. (2008). Internationalization process of SMEs: Strategies and methods. Masters, Mälardalen University.

Melewar, T. C., \& Smith, N. (2003). The internet revolution: Some global marketing implications. Marketing Intelligence \& Planning, 21(6), 363-369.

Milanzi, M. A. (2012). Export Barrier Perceptions in Tanzania: The Influence of Social Networks. Journal of African Business, 13(1), 29-39.

Myszak, J. (2010). Organizational Culture and its Influence on the Effectiveness of the Company. Management Business Innovation, 6(1), 25-29

Mori, N. (2010). Implications of the Marketing Strategy for Exporting MSEs from Developing Economies. Available at SSRN: http://ssrn.com/abstract=1507046 or http://dx.doi.org/10.2139/ssrn.1507046

Obra, A., Cámara, S. B., \& Meléndez, A. P. (2002). Internet usage and competitive advantage: The impact of the internet on an old economy industry in Spain. Internet Research, 12(5), 391-401.

Owusu, R. A., \& Habiyakare, E. (2011). Managing risk and turbulence in internationalization of foreign companies to South Africa: Lessons from seven Finnish business-to-business firms. Journal of African Business, 12(2), 218-237.

Peterson, A. R., Balasubramanian, S., \& Bronnenberg, J. B. (1997). Exploring the implications of the internet for consumer marketing. Journal of the Academy of Marketing Science, 25(4), 329-346.

Poon, S., \& Swatman, P. M. C. (1999). An exploratory study of small business internet commerce issues. Information \& Management, 35(1), 9-18.

Qualman, E. (2009). How social media transforms the way we live and do business. In E. Qualman (ed.), Business Book Summaries, Vol. 1. EBSCO Publishing Inc.

Shabazz, D. (2000). Electronic commerce. Journal of African Business, 1(3), 29-47.

Teo, T. S. H., \& Pian, Y. (2003). A contingency perspective on internet adoption and competitive advantage. European Journal of Information Systems, 12(2), 78-92.

Tesfom, G., Lutz, C., \& Ghauri, P. (2006). Solving export marketing problems of small and medium-sized firms from developing countries. Journal of African Business, 7(1-2), 57-87.

Wilkinson, W. T., \& Brouthers, L. E. (2006). Trade promotion and SME export performance. International Business Review, 15(3), 233-252.

Yi-Long, J., \& Chun-Liang, C. (2006). The influence of the internet in the internationalization of SMEs in Taiwan. Human Systems Management, 25(3), 167-183.

Zhou, L., Wu, W.-p. W., \& Luo, X. (2007). Internationalization and the performance of born-global SMEs: The mediating role of social networks. Journal of International Business Studies, 38, 673-690. 


\begin{abstract}
Polish)
Małe $i$ średnie przedsiębiorstwa odgrywajq istotnq rolę $w$ gospodarkach krajów Afryki Wschodniej, wywierajqc pozytywny wpływ na wysokość dochodu narodowego i poziom zatrudnienia. Prowadzenie działalności eksportowej oferuje dodatkowq możliwość rozwoju tych przedsiębiorstw i poprawę ich funkcjonowania. Jednocześnie przedsiębiorstwa doświadczajq różnorodnych barier zwiqzanych $z$ dostępnościq i przepływem informacji zarówno przed jak i w trakcie prowadzenia działalności eksportowej. Celem pracy jest identyfikacja barier informacyjnych i podjęcie dyskusji nad wpływem internetu na ich przezwyciężanie. W oparciu o literaturę przedmiotu z zakresu internetu, międzynarodowego biznesu i małych przedsiębiorstw, autorzy formułujg tezy i proponuja model badawczy, który może być wykorzystany w przyszłych badaniach naukowych.

Słowa kluczowe: MSP, bariery informacyjne, Internet, eksport, Wspólnota Afryki Wschodniej.
\end{abstract}

